\title{
Hormonal Profile And Histopathological Study On The Influence Of Silymarin On Both Female And Male Albino Rats
}

\author{
Enas A.M.Khalil \\ National Organization for Drug control and Research
}

\begin{abstract}
Silymarin is a mixture of flavonoids extracted from seeds of milk thistle (Silybum marianum [L] Gaertn ). Extracts of S. marianum have been used in the treatment of liver diseases for more than 2000 years.

Flavonoids are a large group of polycyclic phenols of plant origin. Flavonoids displaying estrogenic effects (phytoestrogen).

Phytoestrogens show an estrogenic activity owing to the structural similarity with the estrogen skeleton ,mimicking natural estrogens, it binds to estrogen receptor and modulates its activity. These effects cause complex changes inducing a shift in an overall hormonal balance of the individual. Long term intake of feeds with a higher content of phytoestrogens can induce transient or permanent infertility.

Silybum marianum leaves have been traditionally used in Egypt for their antifertility effects .Also, the antifertility property of silybum marianum leaves was investigated in female albino rats. This property highlights the impotance to clarify the role of silymarin (420mg /day ) a human therapeutic dose on both female and male albino rats.

Silymarin $(151.2 \mathrm{mg} / \mathrm{kg} \mathrm{BW})$ prevented pregnancy in adult female albino rats on days $1-5$ post coitum. In female rats the follicle stimulating hormone (FSH) displayed marked increase, while the luteinizing hormone (LH) and estradiol remained within normal levels. These results showed a distinct increase in number and size of ovarian growing follicles while the effect of silymarin on the uterine wall was in the form of hypertrophy of endometrial epithelium, also increase in the number of uterine glands. Ovaries taken from females treated with silymarin for one and two months contained a large number of growing follicles.

In male rats treated with silymarin $(151.2 \mathrm{mg} / \mathrm{kg} \mathrm{BW})$ for one month, testosterone and $\mathrm{LH}$ were increased significantly, meanwhile estradiol not changed. Testes of rats treated with silymarin for one month showed well developed spermatogenesis with lot of sperms. The epididymis of the same group contained a heavy number of sperms. While rats treated with silymarin for two months displayed significant decrease in serum testosterone levels, while LH and estradiol not changed. These rats displayed some tubules contained well developed spermatogenic layer and normal leyding cells, others appeared moderated by affected. The epididymis contained less number of sperms.

These results indicated that silymarin $(151.2 \mathrm{mg} / \mathrm{kgBW}$ ) a dose equivalent to human therapeutic dose $(420 \mathrm{mg} /$ day) prevented pregnancy in female rats and caused some histological changes in the ovary and uterus, while it has biological benefits for male rats during short treatment.
\end{abstract}

\section{Introduction}

Silymarin is a mixture of flavonoids extracted from seeds of milk thistle (silybum marianum [ L.] Gaertn ) which contains silybin, silydianin, and silychristin as the major constituents. (Morazzoni and
Bombardelli,1995). Silymarin is a hepatoprotective (Schriewer et al.,1975), cytoprotective (Valenzuela et al. ,1985; Valenzuela et al. ,1987; Muriel et al.,1992 ; Schonfeld et al. ,1997; Sonnenbichler et al. , 1999), 
hypoglycemic (Velussi et al., 1993), hypocholesterolemic (Krecman et al. ,1998) , has anticarcinogenic effects ( $\mathrm{Zi}$ et al. , 1998 ; Zi and Agarwal ,1999 and Kohno et al., 2002), gastro-protective and /or anti-ulcer properties (Borrelli and Izzo, 2000 ) .It has been reported that the action of silymarin resulted from the strong antioxidant activity ( inhibition of generation and scavenging of free radicals), inhibition of lipid peroxidation in cell membranes, in the stimulation of RNA polymerase and biosynthesis of cell proteins, and in a strong inhibition of enzymes catalyzing the production of leukotrienes and prostaglandins such as 5lipoxygenase and cyclooxygenase (Valenzuela and Garrido , 1994 ; Robak and Gryglewski ,1996 \& de Groot and Rauen ,1998).

Safe, (1995) and Humphrey, (1999) remembered that ingestion of high levels of phytoestrogens can produce adverse effects on reproductive end-point including fertility in various animal species. Also they added high doses of dietary phytoestrogens may be associated with the increased incidence of reproductive problems in men. Kummer et al., (2001) reported that silymarin displayed estrogen effects in ovariectomized rats. Khalil, (2003) recorded the contraceptive effects of hot water extract of Silybum marianum leaves in female albino rats.

These results highlight the importance of clarification the role of silymarn in a dose equivalent to human therapeutic dose $420 \mathrm{mg} /$ day on both female and male albino rats.

\section{Materials and Methods}

\section{I-Chemicals}

Silymarin was obtained from Chemical Industries Development (CID) Laboratories Giza Egypt. The dose was calculated in relation to the therapeutic dose in humans according to (Paget and Barnes, 1965)

The dose $(151.2 \mathrm{mg} / \mathrm{Kg} \quad \mathrm{Bw})$ emulsified with two drops $10 \%$ tween 80 in distilled water. Equivalent solvent vehicles were used for control groups.

\section{II-Bioassay of antifertility}

The inbred adult female albino rats of 120-140 gm were smeared every morning and those of proestrous or estrous days of cycle were selected. Male fertile rats were caged with females .The vaginal smears of such female rats were examined the following morning for evidence of copulation, the rats which showed thick clumps of spermatozoa in vaginal smear were considered as day- 1 of pregnancy.

The pregnant females were divided into four groups each of 10 . Gr. I were administered $151.2 \mathrm{mg} / \mathrm{kg} \mathrm{B.W}$. p.o. for 5 days , Gr. II were administered the vehicle for 5 days .The animals were autopsied on day 16 and the number of pregnant animals of implantation sites within each control and treated group was recorded

( Woo et al,.1986 ) .

\section{Experimental design Animals}

48 adult albino rats were used, the rats were divided into three groups . Gr.I which represented control group contains 24 rats (12 females and 12 males) caged individually and was administered the vehicle. Gr.II contains $12 \operatorname{rats}\left(6 q+6{ }^{\Uparrow}\right)$ caged individually and treated with silymarin $151.2 \mathrm{mg} / \mathrm{kg} \mathrm{B} . W$. for 4 weeks . Gr . III contains $12 \operatorname{rats}(6+9+6 \AA)$ caged individually and treated with silymarin $151.2 \mathrm{mg} / \mathrm{kg}$ B.W. for 8 weeks.

\section{Body weights}

Body weights of rats were recorded before treatment, weekly, for 4 and 8 weeks.

\section{Blood sampling}

Blood samples were collected from retro-orbital plexus (Schermer ,1967) . An aliquot from blood samples was collected into test tubes with EDTA for determination of some hematological parameters . Red blood cells and white blood cells were estimated by using Heamocytometer. Haemoglobin was determined by using Haemometer. the rest of the blood samples used for separation of serum for bioassay of 


\section{Enas A.M.Khalil}

some reproductive hormones The Roche Elecsys $1010 \mathrm{imm}$-unoassay analyser for in vitro quantitave determination of serum estradiol, FSH and LH for female albino rats and serum testosterone, estradiol and $\mathrm{LH}$ for male rats. (using kits from the Roche Diagnostics Gmbh ) Mannheim, Germany. The data were statistically analyzed using student's t-test according to (Sendecor and Coebram,1969). In addition histopatholo-gical studies were carried out by collecting the specimens from ovaries, uteri, testes and epididymis. These specimens were fixed in $10 \%$ neutral formalin and bouin fixatives. 5 micron thick paraffin sections were prepared, stained with hematoxylin \& eosine and examined microscopically.

\section{Results}

\section{A-Biochemical results}

Table I showed that silymarin $(151.2 \mathrm{mg} / \mathrm{kg}$ BW ) prevented pregnancy on days 1-5 in adult female albino rats.

The data shown in table (2) revealed that silymarin induced significant increase in body weight, in the concentration of haemoglobin and erythrocyte count not affected compared to the control values for both sexes. But no significant decrease in leucocyte counts at the two experimental periods was observed. In female rats serum FSH increased significantly about more than twofold, while serum estradiol was remained within normal at the two experimental periods which resembles hormonal profile of the old ones and insisted on prevention of pregnancy. Serum LH was within normal in comparison with control values at 4 and 8 weeks table (3). In male rats treated with silymarin (151.2 $\mathrm{mg} / \mathrm{kg} \mathrm{BW}$ ) for one month, testosterone and LH were increased significantly, meanwhile estradiol not changed. While rats treated with silymarin for two months displayed significant decrease in serum testosterone levels, while LH and estradiol not changed

\section{B-Histological results}

It was noticed that ovaries taken from adult female rats treated with silymarin for one and two months contained a large number of growing follicles (figs.2,3) compared with control (fig.1).Uterine endometrial epithelium showed hypertrophy with increased proliferation (fig5) compared with control one (fig.4). The endometrial epithelium was of tall columnar type with numerous glands (fig.6). testes taken from adult males treated with silymarin for one month showed that, there was complete series of spermatogenesis in the lumen of the active mature seminiferous tubules with apparently histological structure of both leyding and sertoli cells (fig.8)compared with control one (fig7), this was accompanied with increased number of sperms in the epididymis of the same group (fig.11) compared to the control one (fig.10).

While in males treated with silymarin for two months, some somniferous tubules appeared normal and so on leyding cells ,others appeared moderate by affected but still have their architecture with reduced number of different spermtogenic cells specially sperms and so leyding cells(fig.9), this was accompanied with reduced number of mature sperms in the epididymis of the same group (fig.12).

Table I : Contraceptive efficacy of silymarin $151.2 \mathrm{mg} / \mathrm{kg} \mathrm{B.W}$.

\begin{tabular}{|l|l|l|l|}
\hline Groups & $\begin{array}{l}\text { Dose } \mathrm{mg} / \mathrm{kg} / \text { day } \\
\text { P.O. }\end{array}$ & Post-coitum & $\begin{array}{l}\text { No. of pregnant / } \\
\text { No. of treated }\end{array}$ \\
\hline Gr. I & $151.2 \mathrm{mg} / \mathrm{kg} \mathrm{B.W.}$ & $1-5$ & $0 / 10$ \\
\hline Gr. I I & Received the vehicle & $1-5$ & $10 / 10$ \\
\hline
\end{tabular}

Group I administered silymarin ( $151.2 \mathrm{mg} / \mathrm{kg} \mathrm{B.W.} \mathrm{)} \mathrm{for} 5$ days.

Group II administered the vehicle for 5 days. 
Table (2) : Showing the changes of of body weight \& some haematological parameters of normal rats treated with silymarin $(151.2 \mathrm{mg} / \mathrm{kg} \mathrm{B}$.W) daily for $4 \& 8$ weeks.

\begin{tabular}{|c|c|c|c|c|c|}
\hline \multirow[t]{2}{*}{ Groups } & \multirow{2}{*}{$\begin{array}{c}\text { Time } \\
\text { intervals }\end{array}$} & Body weights & Haemoglobin & $\mathrm{RBCs}$ & WBCs \\
\hline & & $\mathrm{g}$ & $\mathrm{g}$ & $10^{6} / \mathrm{cmm}$ & $10^{3} / \mathrm{cmm}$ \\
\hline $\begin{array}{c}\text { Gr.I } \\
\mathrm{n}=24 \\
\left(12 q+12{ }^{\Uparrow}\right)\end{array}$ & 0 time & $\begin{array}{r}125 \\
\pm 5.22\end{array}$ & $\begin{array}{c}15 \\
\pm 0.89\end{array}$ & $\begin{array}{c}6 \\
\pm 0.26\end{array}$ & $\begin{array}{c}9 \\
\pm 0.44\end{array}$ \\
\hline $\begin{array}{c}\text { Gr.II } \\
\mathrm{n}=12 \\
(6++6 \AA)\end{array}$ & 0 time & $\begin{array}{c}129.33 \\
\pm 5.8\end{array}$ & $\begin{array}{r}15.33 \\
\pm 0.75\end{array}$ & $\begin{array}{c}6.1 \\
\pm 11\end{array}$ & $\begin{array}{c}9.15 \\
\pm 0.27\end{array}$ \\
\hline $\begin{array}{c}\text { Gr.III } \\
n=12 \\
\left(6 \bigcirc+6 \bigcirc^{\top}\right)\end{array}$ & 0 time & $\begin{array}{l}132.33 \\
\pm 6.62 \\
\end{array}$ & $\begin{array}{r}15.2 \\
\pm 0.6\end{array}$ & $\begin{array}{c}6.16 \\
\pm 0.18 \\
\end{array}$ & $\begin{array}{r}8.99 \\
\pm 0.4\end{array}$ \\
\hline $\begin{array}{c}\text { Gr.I } \\
n=12 \\
\left(6 \bigcirc+6 \bigcirc^{\lambda}\right)\end{array}$ & 4 weeks & $\begin{array}{r}145 \\
\pm 4.5 \\
\end{array}$ & $\begin{array}{r}15.5 \\
\pm 0.55 \\
\end{array}$ & $\begin{array}{r}6.2 \\
\pm 0.22 \\
\end{array}$ & $\begin{array}{r}8.99 \\
\pm 0.5 \\
\end{array}$ \\
\hline $\begin{array}{c}\text { Gr.II } \\
\mathrm{n}=12 \\
\left(6++6{ }^{\lambda}\right)\end{array}$ & 4weeks & $\begin{array}{l}160^{* \uparrow} \\
\pm 3.29 \\
\end{array}$ & $\begin{array}{r}17 \\
\pm 1 \\
\end{array}$ & $\begin{array}{r}6.78 \\
\pm 0.29 \\
\end{array}$ & $\begin{array}{l}7.49^{*} \downarrow \\
\pm 0.52 \\
\end{array}$ \\
\hline $\begin{array}{c}\text { Gr.I } \\
\mathrm{n}=12 \\
\left(6 \bigcirc+6 \bigcirc^{\lambda}\right)\end{array}$ & 8 weeks & $\begin{array}{l}167 \\
\pm 3 \\
\end{array}$ & $\begin{array}{r}16 \\
\pm 1\end{array}$ & $\begin{array}{c}6.5 \\
\pm 0.3\end{array}$ & $\begin{array}{r}8.82 \\
\pm 0.5\end{array}$ \\
\hline $\begin{array}{c}\text { Gr.III } \\
n=12 \\
\left(6 q+6 \bigcirc^{\Uparrow}\right)\end{array}$ & 8 weeks & $\begin{array}{l}180^{* * \uparrow} \\
\pm 2.25 \\
\end{array}$ & $\begin{array}{r}18 \\
\pm 1 \\
\end{array}$ & $\begin{array}{c}8 \\
\pm 0.93 \\
\end{array}$ & $\begin{array}{c}6.53^{* *} \downarrow \\
\pm 0.46 \\
\end{array}$ \\
\hline
\end{tabular}

Gr.I=control group,Gr.II=group treated with silymarin $(151.2 \mathrm{mg} / \mathrm{Kg} \mathrm{B.W})$ for 4 weeks, Gr. III=group treated with silymarin $(151.2 \mathrm{mg} / \mathrm{KgB} . \mathrm{W})$ for 8 weeks and were statistically analyzed from their corresponding controls.

Insignificant difference from the corresponding control at $\mathrm{P}>0.05$

*Significant difference from the corresponding control at $\mathrm{P}<0.05$

** Significant difference from the corresponding control at $\mathrm{P}<0.01$

*** Significant difference from the corresponding control at $\mathrm{P}<0.001$ 


\section{Enas A.M.Khalil}

Table (3) : Showing the changes of FSH, LH and estradiol of adult female albino rats treated with silymarin $(151.2 \mathrm{mg} / \mathrm{kg} \mathrm{BW})$ daily for periods 4 and 8 weeks.

\begin{tabular}{|c|c|c|c|c|}
\hline \multirow{2}{*}{ Groups } & \multirow{2}{*}{ Time intervals } & FSH & $\mathrm{LH}$ & Estradiol \\
\hline & & $\mathrm{ng} / \mathrm{ml}$ & $\mathrm{ng} / \mathrm{ml}$ & $\mathrm{pg} / \mathrm{ml}$ \\
\hline $\begin{array}{l}\text { Gr. I } \\
n=12 \text { 이 }\end{array}$ & 0 time & $\begin{array}{l}0.164 \\
\pm 0.09\end{array}$ & $\begin{array}{l}1.8 \\
0.2 \pm\end{array}$ & $\begin{array}{l}19 \\
1.1 \pm\end{array}$ \\
\hline $\begin{array}{l}\text { Gr. II } \\
\mathrm{n}=12 \text { 9 }\end{array}$ & 0 time & $\begin{array}{l}0.165 \\
0.07 \pm\end{array}$ & $\begin{array}{l}2 \\
0.1 \pm\end{array}$ & $\begin{array}{l}18 \\
1 \pm\end{array}$ \\
\hline $\begin{array}{l}\text { Gr. III } \\
\mathrm{n}=12 \text { ? }\end{array}$ & 0 time & $\begin{array}{l}0.16 \\
0.05 \pm\end{array}$ & $\begin{array}{l}1.9 \\
0.1 \pm\end{array}$ & $\begin{array}{l}20 \\
2 \pm\end{array}$ \\
\hline $\begin{array}{l}\text { Gr. I } \\
\mathrm{n}=6 \text { 우 }\end{array}$ & 4 weeks & $\begin{array}{l}0.16 \\
\pm 0.05\end{array}$ & $\begin{array}{l}2 \\
0.1 \pm\end{array}$ & $\begin{array}{l}19 \\
1 \pm\end{array}$ \\
\hline $\begin{array}{l}\text { Gr. II } \\
\mathrm{n}=6 \text { 우 }\end{array}$ & 4 weeks & $\begin{array}{c}0.38^{*} \uparrow \\
\pm 0.05\end{array}$ & $\begin{array}{l}2.3 \\
0.1 \pm\end{array}$ & $\begin{array}{l}22 \\
1 \pm\end{array}$ \\
\hline $\begin{array}{l}\text { Gr.I } \\
\mathrm{n}=6 \text { 우 }\end{array}$ & 8 weeks & $\begin{array}{l}0.17 \\
\pm 0.05\end{array}$ & $\begin{array}{l}2.1 \\
0.1 \pm\end{array}$ & $\begin{array}{l}20 \\
1 \pm\end{array}$ \\
\hline $\begin{array}{l}\text { Gr. III } \\
\mathrm{n}=6 \text { 우 }\end{array}$ & 8 weeks & $\begin{array}{l}0.58^{* * \uparrow} \\
0.1 \pm\end{array}$ & $\begin{array}{l}2.3 \\
0.1 \pm\end{array}$ & $\begin{array}{l}23 \\
1 \pm\end{array}$ \\
\hline
\end{tabular}

Gr.I=control group,Gr.II=group treated with silymarin $(151.2 \mathrm{mg} / \mathrm{Kg}$ B.W $)$ for 4 weeks , Gr.III=group treated with silymarin $(151.2 \mathrm{mg} / \mathrm{KgB} . \mathrm{W})$ for 8 weeks and were statistically analyzed from their corresponding controls.

Insignificant difference from the corresponding control at $\mathrm{P}>0.05$

*Significant difference from the corresponding control at $\mathrm{P}<0.05$

** Significant difference from the corresponding control at $\mathrm{P}<0.01$

*** Significant difference from the corresponding control at $\mathrm{P}<0.001$ 
Table (4) : Showing the changes of testosterone, $\mathrm{LH}$ and estradiol of adult male albino rats treated with silymarin $(151.2 \mathrm{mg} / \mathrm{kg} \mathrm{BW})$ daily for periods 4 and 8 weeks.

\begin{tabular}{|c|c|c|c|c|}
\hline \multirow{2}{*}{ Groups } & \multirow{2}{*}{ Time intervals } & Testosterone & $\mathrm{LH}$ & Estradiol \\
\hline & & $\mathrm{ng} / \mathrm{ml}$ & $\mathrm{ng} / \mathrm{ml}$ & $\mathrm{pg} / \mathrm{ml}$ \\
\hline $\begin{array}{c}\text { Gr. I } \\
\mathrm{n}=12{ }^{\lambda}\end{array}$ & Otime & $\begin{array}{c}1.2 \\
\pm 0.07\end{array}$ & $\begin{array}{c}0.35 \\
\pm 0.004\end{array}$ & $\begin{array}{c}4.3 \\
\pm 0.5\end{array}$ \\
\hline $\begin{array}{c}\text { Gr. II } \\
\mathrm{n}=12 \hat{\diamond}\end{array}$ & 0 time & $\begin{array}{c}1.3 \\
\pm 0.08\end{array}$ & $\begin{array}{c}0.36 \\
\pm 0.005\end{array}$ & $\begin{array}{c}4.4 \\
\pm 0.6\end{array}$ \\
\hline $\begin{array}{l}\text { Gr. III } \\
\mathrm{n}=12{ }^{\lambda}\end{array}$ & 0 time & $\begin{array}{c}1.4 \\
\pm 0.08\end{array}$ & $\begin{array}{c}0.37 \\
\pm 0.006\end{array}$ & $\begin{array}{c}4.5 \\
\pm 0.8\end{array}$ \\
\hline $\begin{array}{c}\text { Gr. I } \\
n=6{ }^{\lambda}\end{array}$ & 4 weeks & $\begin{array}{c}2.5 \\
\pm 0.08\end{array}$ & $\begin{array}{c}0.36 \\
\pm 0.02\end{array}$ & $\begin{array}{c}4.3 \\
\pm 0.5\end{array}$ \\
\hline $\begin{array}{l}\text { Gr. II } \\
n=6{ }^{\lambda}\end{array}$ & 4 weeks & $\begin{array}{c}3 * \uparrow \\
\pm 0.1\end{array}$ & $\begin{array}{c}0.5 \uparrow \\
\pm 0.05\end{array}$ & $\begin{array}{c}4.2 \\
\pm 0.5\end{array}$ \\
\hline $\begin{array}{c}\text { Gr.I } \\
n=6{ }^{\lambda}\end{array}$ & 8 weeks & $\begin{array}{c}2.8 \\
\pm 0.2\end{array}$ & $\begin{array}{c}0.36 \\
\pm 0.02\end{array}$ & $\begin{array}{c}4.4 \\
\pm 0.2\end{array}$ \\
\hline $\begin{array}{l}\text { Gr. III } \\
n=6{ }^{\lambda}\end{array}$ & 8 weeks & $\begin{array}{l}2.5 \downarrow \\
\pm 0.2\end{array}$ & $\begin{array}{c}0.4 \\
\pm 0.02\end{array}$ & $\begin{array}{c}5.5 \\
\pm 0.4\end{array}$ \\
\hline
\end{tabular}

Gr.I=control group, Gr.II=group treated with silymarin $(151.2 \mathrm{mg} / \mathrm{Kg} \mathrm{B.W})$ for 4 weeks, Gr.III=group treated with silymarin $(151.2 \mathrm{mg} / \mathrm{KgB} . \mathrm{W})$ for 8 weeks and were statistically analyzed from their corresponding controls.

Insignificant difference from the corresponding control at $\mathrm{P}>0.05$

* Significant difference from the corresponding control at $\mathrm{P}<0.05$

** Significant difference from the corresponding control at $\mathrm{P}<0.01$

*** Significant difference from the corresponding control at $\mathrm{P}<0.001$

\section{Legend of figures}

Fig. (1): Control rat ovary showing few number of growing follicles. H\&Ex500

Fig. (2): Rat ovary treated with silymarin $(151.2 \mathrm{mg} / \mathrm{kg}$ B.w.) showing increased number and size of growing follicles. H\&Ex250.

Fig. (3): Rat ovary treated with silymarin $(151.2 \mathrm{mg} / \mathrm{kg} \mathrm{Bw})$ showing increased number and size of growing follicles. H\&Ex500

Fig. (4): Control rat uterus showing lining epithelium and few number of uterine gland. H\&E $\mathbf{x} 250$

Fig. (5): Rat uterus in group treated with silymarin $(151.2 \mathrm{mg} / \mathrm{kg}$ B.w.) showing signs of hypertrophy (h).

H\&E x 500

Fig. (6) : Rat uterus in group treated with silymarin $(151.2 \mathrm{mg} / \mathrm{kg}$ B.w.) showing tall columnar epithelium $(\uparrow)$ and increased number and size of uterine glands $(\uparrow \uparrow)$, with signs of hypertrophy (h). H\&E x 500

Fig. (7) : Control rat testis showing complete series of spermatogenesis in the lumen of the active mature somniferous tubules with apparently histological structure of both leyding and sertoli cells. H\&Ex500

Fig.(8): Rat testis in group treated with silymarin $(151.2 \mathrm{mg} / \mathrm{kg} \mathrm{B.w.)}$ for one month showing well developed seminiferous tubules and well developed spermatogenetic activity and leyding cells. $H \& E$ x 500

Fig.(9): Rat testis in silymarin treated group for two months showing some tubules appeared normal but some tubules appeared moderately affected and contained less number of spermatic cells especially sperms, also leyding cells appeared moderately affected. H\&E x250

Fig.(10) : Epididyms of control group consisted of pseudo esterified ciliated columnar cells with non motile cilia , this layer rests on the outer basement membrane. H\&Ex 250

Fig. (11) : Epididyms of silymarin treated rat for one month contained lot of sperms. H\&E x500

Fig.(12) : Epididyms of silymarin treated rat for two months contained less number of sperms compared to control. H\&E x500 

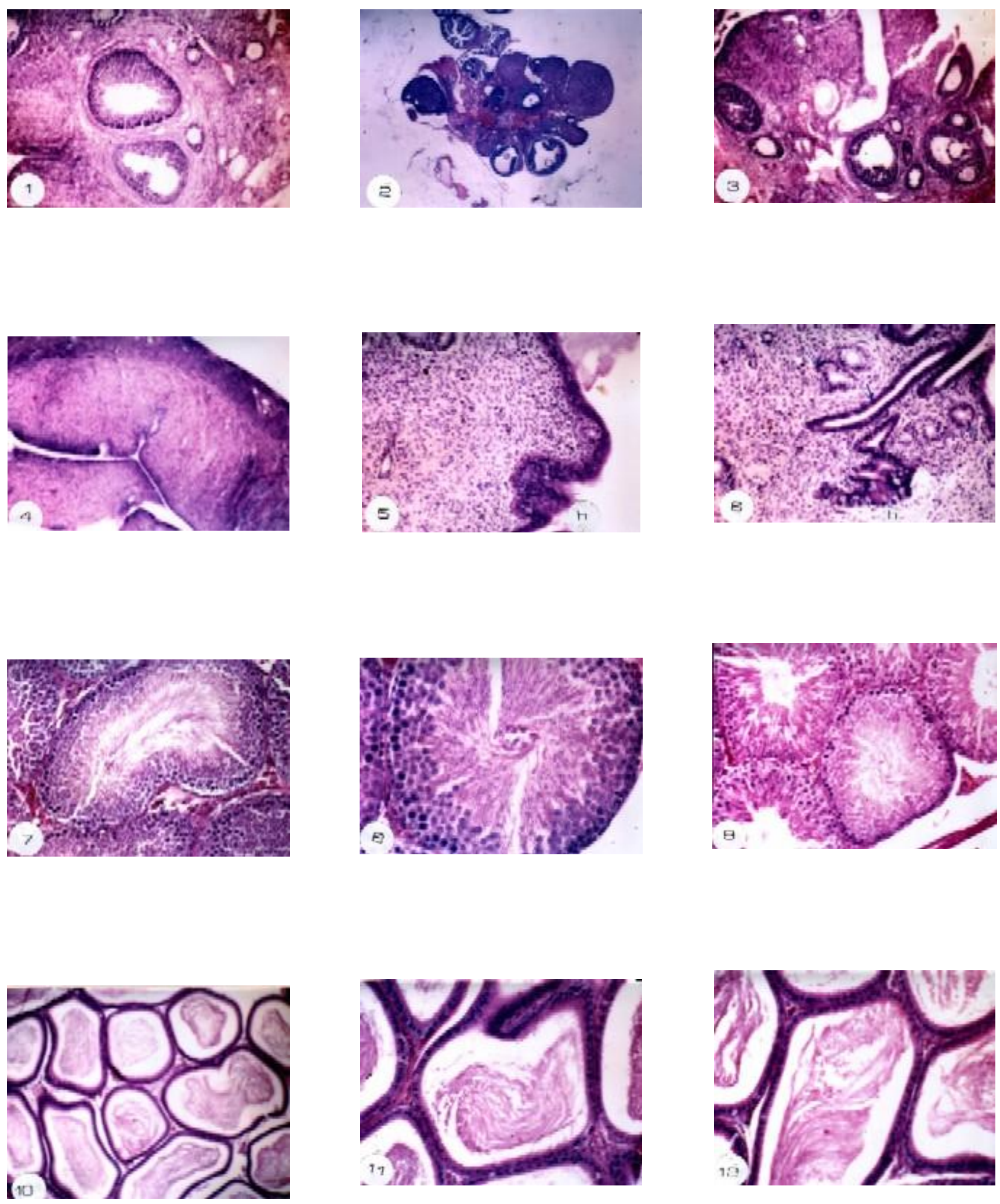


\section{Discussion}

The objective of this study was to test whether silymarin induces changes in the fertility of male and female rats. Intensive attention has been paid to flavonoids displaying estrogenic effects (non-steroidal estrogenic, phytoestrogens).

This experiment indicated that silymarin (151.2 mg / kg BW /day p.o.) prevented pregnancy in adult female albino rats on days 1-5 post coitum (table1).The marked increase more than twofold in serum FSH levels (table3) by silymarin treatment which insisted on prevention of pregnancy and resembles with serum FSH values of old rats and of women at postmenopausal (Huang et al., 1978 and Felig et al., 1995).

The present study showed that silymarin treatment led to unaltered change in serum LH(table3) . Hughes et al. (,1991) found that the lowest dose of coumesterol (phytoestrogen) suppressed basal LH levels , whereas higher doses had no detectable effect.

No changes in serum estradiol levels could be detected (table 3 ). It was found that no surges in serum estradiol in old rats (Huang et al., 1978)

Chen , (1998) ; Messina, (1999) and Hodek et al., (2002) stated that phytoestrogens show an estrogenic activity owing to the structural similarity with the estrogen skeleton ,mimicking natural estrogens, it binds to estrogen receptor and modulates its activity . These effects cause complex changes inducing a shift in an overall hormonal balance of the individual, resulting in various affects e.g transient or permanent infertility and decrease in postmenopausal symptoms.

Estrogen plays an important role in female reproductive system. In mammals structural change in vagina, uterus and ovary are affected by estrogens (Turner and Bagnara1976). Proliferation of gonadal tissues and increase of uterine weight could be detected in animals treated with estrogenic activity flavonoids (Santell et al,1997).

These results are in agreement with these results since uterine endometrial epithelium appeared hypertrophied with tall columnar cells and increased size and number of uterine glands. This was accompanied by increased growing follicles. The same result was obtained by (ElGarieb,2001).

In male rats ,a significant increase of serum testosterone and LH levels while estradiol did not change by silymarin treatment at one month. Oliveira et al., (2001) confirmed that estrogen is required for normal function of the efferent ductules and is essential for long -term fertility in male rodent. Robertson et al., (2002) insisted that low levels of dietary phytoestrogen have a biological effect in the testis. Vermeulen et al.,(2002) states that estrogen play an important role in the regulation of the gonadotrobin feedback , several brain functions, bone maturation, regulation of bone resorption, they affect skin metabolism and an important factor determing sex interest in man .

While rats treated with silymarin for two months displayed significant decrease in serum testosterone levels, while $\mathrm{LH}$ and estradiol not changed. This result is attributed to enzyme regulation for testosterone synthesis which may be affected by phytoestrogen rich diet and decreased testosterone levels Weber et al., (2001).

Hodek et al., (2002) noticed that flavones and flavonone have higher aromatase (This enzyme catalyzes a unique reaction, aromatization of the A ring of male sex steroids to estrogens ) inhibitory activity .Silymarin is considered an aromatase inhibitor. Kaneto et. al, (1999) noticed that ethinyl estradiol affects epididymal spermatozoa before testicular germ cells via a testosterone deficieincy ,when it is administered at extremely high doses.

No changes in serum LH or estradiol levels were observed that could account for changes in the observed testosterone levels. Males treated with silymarin for one month appeared developed with intense appearance of sperms the same picture could be noticed in the epididymis. While adult male 


\section{Enas A.M.Khalil}

rats treated for two months showed moderate damage in some seminiferous tubules with detectable inhibition in the spermotogenic activity and decreased number of cells in the different spermotogenic layers specially sperms

The significant increase in body weights of both sexes in this study was attributed to silymarin stabilization action to the liver membranes which exerted protection to the hepatocytes and improved liver function (Faulstich et al., 1982), moreover silymarin has shown to stimulate RNA and protein synthesis and subsequently improved growth and increased bodyweight (Sonnenbicher and Zelt, 1986, 1987 and 1992). The unaltered changes of $\mathrm{Hb}$ and erythrocyte count due to the hypothesis that the flavonoid is a cytoprotective agent, can inhibit hemolysis and lipid peroxidation (Valenzuela et al., 1987).

In conclusion, it can be postulated that silymarin has a definite estrogenic effect which leads to abnormalities in the ovaries and cells of the uterus and can interfere with ova and sperm formation as well as the process of implantation and pregnancy. These data indicated that silymarin (151.2mg $/ \mathrm{kgBW}$ ) as a dose equivalent to human therapeutic dose (420mg/ day) prevented pregnancy in female rats while it has biological benefits for male rats for a definite time. More studies must be needed to detect the sensitivity of hypothalamic-,hypophysial axis and the gonads to silymarin treatment.

\section{References}

1. Borrelli, F., and Izzo, A. (2000): The plant kingdom as a source of anti-ulcer remedies.Phytother Res Dec.14(8) :581-591

2. Chen, S. (1998): Aromatase and Breast Cancer Front. Biosci. 3, 922-933.

3. de Groot H., and Rauen U.(1998): Tissue injury by reactive oxygen species and the protective effects of flavonoids. Fundam. Clin.Pharmacol. 12,249-255.

4. El-Garieb ,R.(2001): Estrogenic effect of Orthopedic DDT on the female genital organs of mice.The Egyptian Journal of Hospital Medicine vol.:108-120

5. Faulstich, H.; John, W., and Wield, T. (1980): Silibin inhibtion of amatoxin uptake in the perfused rat liver Arzneim.Forsch/Drug Res., 30, 445-454.

6. Felig, P.;Baxter J. and Frohman L (1995): Endocrinology and Metabolism $3^{\text {rd }}$ Ed .McGRaw-Hill,inc Health Professions Division p.301

7. Hodek, P.; Trefil, P.; and Stiborova, M. (2002): Flavonoids-potent and versatile biologically active compounds interacting with cytochromes P450. ChemicoBiological Interactions; 139.

8. Huang,H..; steger,R;and Bruni ,J.( 1978) : Patterns of sex steroid and gonadotropin secretion in aging female rats. Endocrinol. ,103, No.5;1855-1860.

9. Hughes, Jr; Kaldas , R ., and Weisinger, A. (1991): Acute and subacute effects of naturally occuring estrogens on luteinizing hormone secretion in the ovariectomized rats:part1.Reprod Toxicol 5:127-132.

10. Humfrey, C.D. (1998) : Phytoestrogens and human health effects. Weighing up the current evidence .Natural toxins, vol6, issue 2,p51.

11. Kaneto,M.; Kanamor I s,Hishikawa A,Kishi K.(1999): Epididymal sperm motion as aparameter of male reproductive toixicity : sperm motion, fertility , and histopathology in ethyinylestradiol -treated rats .Reprod Toxicol ; (4) :279

12. Khalil , E . (2003) :Biochemical and histopathological studies on contraceptive effects of hot water extract of Silybum marianum leaves in female albino rats..Egypt J.Biomed.Sci.Vol.II,April

13. Kohno, H.; Tanaka, T.; Kawabata, k.; Hirose, Y.; Sugie, S. ; and Tsuda, H. (2002): Silymarin , a naturally occuring polyphenolic antioxidant flavonoid, inhibits azoxymethane-induced colon cacinogenesis in male F344 rats. Int J. Cancer Oct.10:101(5): 461-8.

14. Krecman, V., Skottova, N.,and Walterova,J., (1998): Silymarin inhibts the Development of diet-induced hyper-cholesterolemia in rats. Planta Medica 64,138

15. Kummer, V.; Maskova, J.; Canderle, J.; Zraly, Z. and Neca, J. (2001):Estrogenic effects of silymarin in ovariectomized rats. Vet. Med. Czech. 46, 17-23.

16. Messina, M.J. (1999): Legumes And Soybeans:Overview of their nutritional profiles and health effects. Am.J. Clin. Nutr.70, 439-450.

17. Morazzoni, P. and Bombardelli, E., (1995) : Silybum marianum (Carduus marianus) . Fitoterapia.66, 3:42 
18. Muriel ,P.; Garciapina T.; Alvarez,V. and Mourel, M. (1992): Silymarin protects against paracetamol -induced lipid peroxidation and liver .J.Appl. Toxicol.12 (6), 439442.

19. Oliveira C.; Carnes K.; Franca L. and Hess R. (2001): Infertililty and testicularatrophy in the antiestrogen-treated adult male rat. Biol Reprod sep;65(3):913

20. Paget ,G.E.and Barnes ,J.M. (1964): In" toxicity tests" Vol.(.I) Chpter (6) p.135 Editor : Laurance,D.R andBacharach,A.L. Academic Press,London,New York.

21. Robak,J. and Gryglewski, R. (1996): Bioactivity of flavonoids.Pol.J.Pharmacol., 48:555.Robertson, K.M.; O,Donnell, L.; Simpson, E.R.and Jones, ME.(2002):The phenotype of the aromatase knockout mouse reveals dietary phytoestrogens impact significantly on testis function. Endocrinology Aug;143(8):2913.

22. Safe SH. (1995) : EnvironHeath Perspect Apr;103(4) : 346-351

23. Santell, R.C.,Chang y.CH., Nair M.G. and Helferich W.G.(1997) : Dietary genistein exerts estrogenic effects upon the uterus ,mammary gland and the hypothalamic/pituitary axis in rats .J.Nutr., 127,263-269

24. Schermer,S.,(1967):The Blood Morpholgy of laboratory animals. 3 rd Ed.Davis Company ,Philadelphia, U.S.A. P. 42. Davis,F.A.Co., New York, Phildeladelphia

25. Sendecor, G. W.and CoeBram, W. C., (1969): In" Statistical Methods". 6 th $^{\text {th }}$ Ed.Iowa State Univ. Press Anes.Iowa, U.S.A., P.70.

26. Sonnenbichler, J. and Zelt, I. (1986): Biochemical Effects of A Flavolignans Silibinin on RNA protien And DNA Synthesis in rat livers. Prog. Clin.Biol.Res., 213: 319

27. Sonnenbichler, J. and Zelt, I. (1987): Stimulating influence of a flavolignane derivative on proliferation, RNA synthesis and protein synthesis in liver cells in assessment and management of hepatobiliary disease. Okolicsanyi I,co.And Gosmos,G,Grepadi G (eds.) p.265-272 Springer Verlag Berlin.

28. Sonnenbichler, J. and Zelt, I. (1992): Biochemistrey of a liver drug from the Thistle Silybum marianum. Planta Med. 58 supplement Issue1, 580.
29. Turner,R.T. and Bagnora,J.T (1976): General endocrinology ,WB Saunders, Philadelphia,ch.14

30. Valenzeuela ,A.; Lagos,C.;Schmid K.and L.A.Videla (1985): Silymarin protection against hepatic lipid peroixdation induced by acute ethanol intoxication in the rat liver. Biochim. Pharmacol. 34,2209-2212.

31. Valenzuela, A.; Guerra, R. and Garrido, A. (1987): Silybin dihemisuccinate protects rat erythrocytes against phenyl hydrazone induced lipid peroxidation and hemolysis. Planta Medica; 53: 402-405.

32. Valenzuela A. and Garrido, A. (1994): Biochemical bases on the pharmacological action on the flavonoids silymarin and of its structural isomer silibinin. Biol.Res ., 27,105-112.

33. Vermeulen, A.; Kaufman, J .M.; S. and Van Pottelberg, 1. (2002): Estradiol in elderly men. Aging Male 2002 Jun.,5(2) :98-102.

34. Weber K.; Setchell, K.; and Lephart, E.(2001): Dietary soy-phytoestrogens decrease testosterone levels and prostate weight without altering $\mathrm{LH}$, prostate $5 \alpha$ reductase or testicular steroidogenic acute regulatory peptide levels in adult spragueDawley rats. J.of Endocrinol.,Sep.170 (3), 591

35. Woo, W.S.; Lee, E.B.; Kong, S.S.; Shin, K.H. and Chi, H.J. (1986): Antifertility Principle of Dictamnus albus Root Bark. Planta Medica; 52: 399-401.

36. Zhao, J. and Agarwal, R.(1999): Tissue distribution of silibinin,the major active constituent of silymarin, in mice and its association with enhancement of phase II enzymes : implication in cancer chemoprevention. arcinogenesis. Nov;20 (11): 2101

37. Zi, X. ; and Agarwal, R. (1999):Silibinin decreases prostate -specific antigen with cell growth inhibition via G1 arrest, leading to differentiation of prostate carcinoma cells: implications for prostate cancer intervention. Proc. Nat Acad Sci USA; 96:7490.

38. Zi, X. ; Feyes , D.; and Agarwal ,R.(1998): Anticarcinogenic effect of a flavonoid antioxidant,silymarin in human breast cancer cells MDA-MB468; induction of G1 arrest through an increase in cip1/p21 concommitant with a decrease in kinase activity cyclin -dependent kinases and associated cyclins. Clin.cancer Res;4: 10555 . 


\section{الوجهة الهر مونيه ودراسة هستوباثولوجيه على تأثير السيليمارين فى كل من إناث وذكور الجرذان البيضاء

\author{
أيناس على مهدى خليل \\ الهيئة القومية للرقابة والبحوث الدوائيه
}

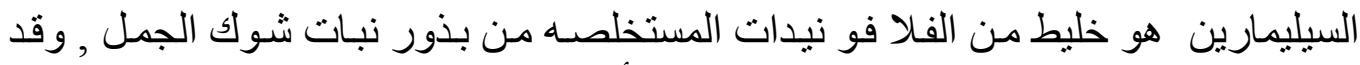

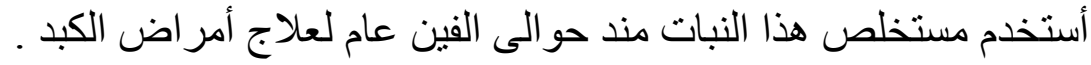

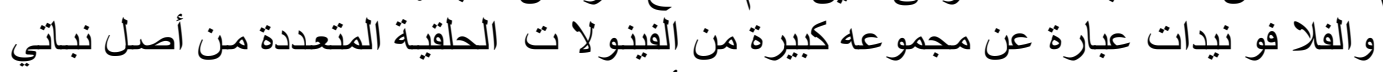

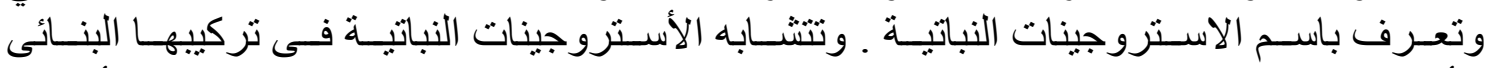

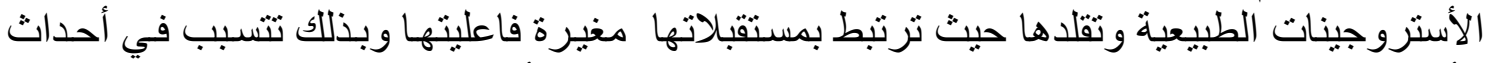

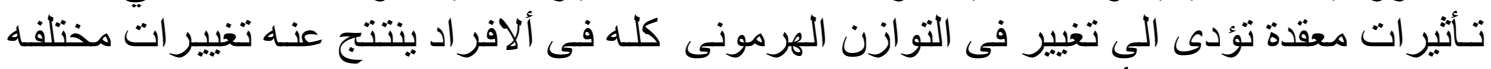

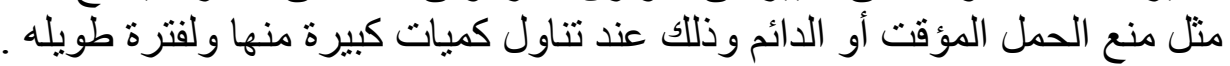

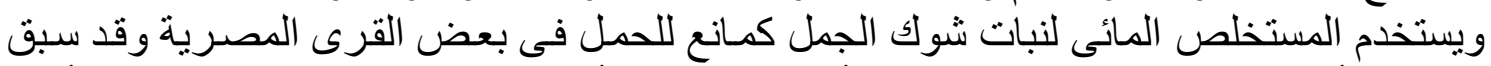

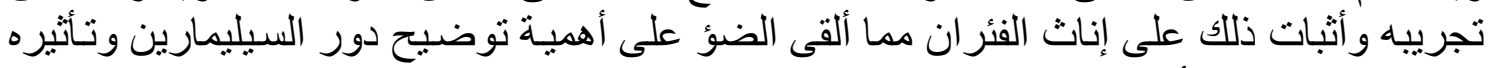

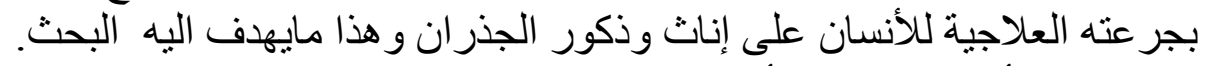

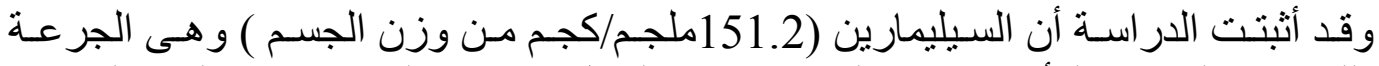

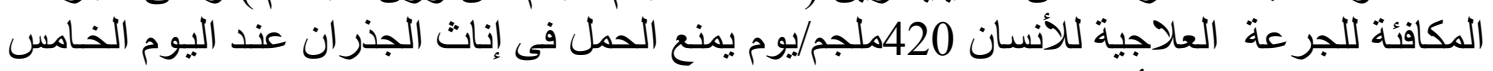

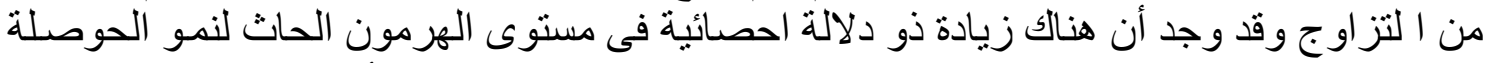

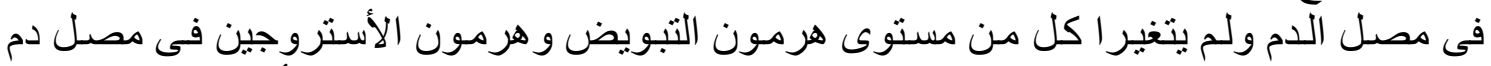

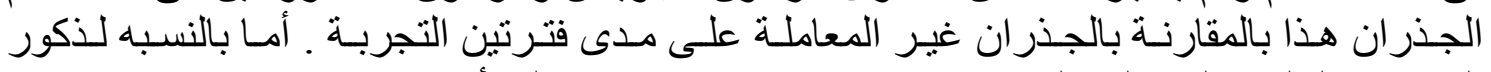

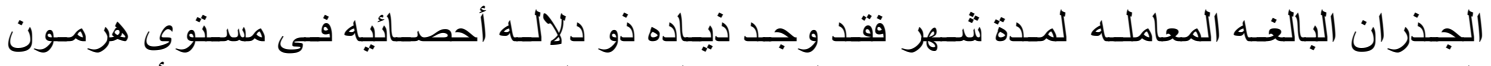

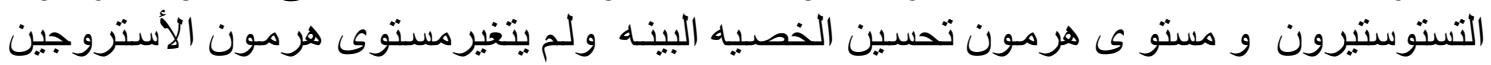

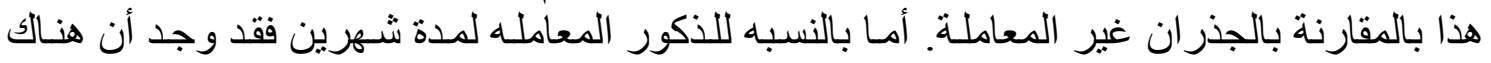

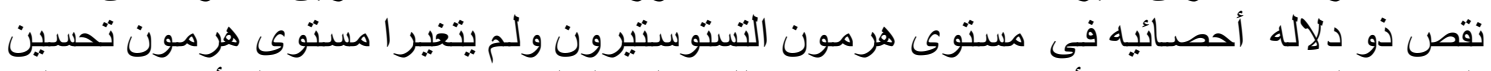

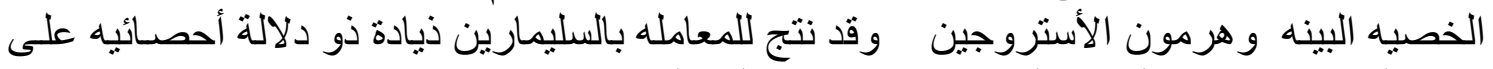

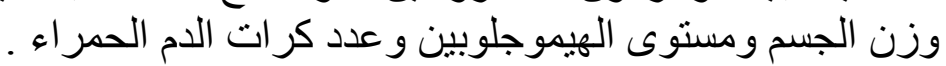

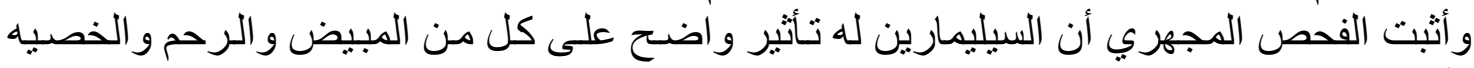

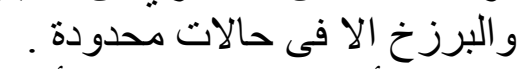

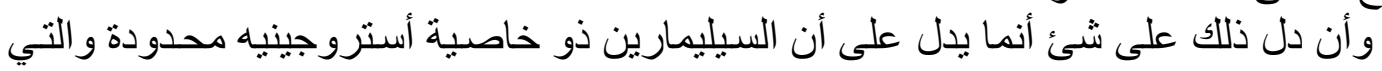

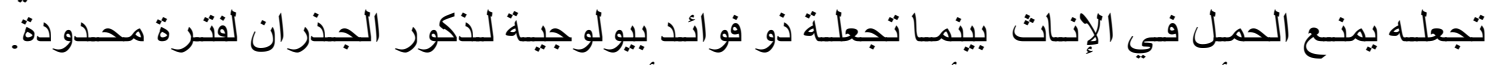

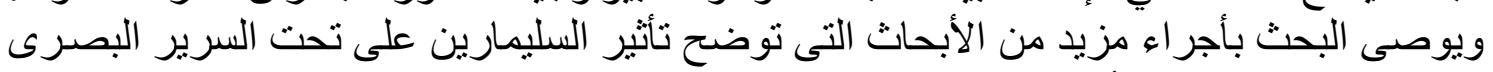
و النخاميه لكل من ذكر و أنثى الثديات . 